\title{
Hubungan Antara Prestasi Belajar dengan Perencanaan Karir
}

\author{
Sidik Apriansyah \\ SMK Muhammadiyah 1 Muntilan \\ Jl. KH Ahmad Dahlan. Gatak. Gamol, RT 01/RW 03 \\ Indonesia \\ Email: sidikaprians@gmail.com
}

\begin{abstract}
Prestasi belajar merupakan salah satu aspek yang mempengaruhi perencanaan karir pada siswa. Penelitian ini bertujuan untuk mengetahui hubungan antara prestasi belajar dengan perencanaan karir pada siswa kelas XI SMA Negeri 2 Bantul. Jenis penelitian ini korelasi yang memiliki dua variabel yaitu variabel prestasi belajar (X) dan variabel perencanaan karir (Y). Populasi dalam penelitian ini adalah siswa kelas XI SMA Negeri 2 Bantul. Sampel dalam penelitian berjumlah 37 siswa kelas XI yang diambil dengan random sampling. Pengumpulan data pada variabel prestasi belajar menggunakan data dokumentasi yaitu data nilai rapor dan pada variabel perencanaan karir menggunakan angket. Analisis data menggunakan analisis korelasi product moment untuk mengetahui hubungan antara prestasi belajar dengan perencanaan karir. Hasil analisis data menunjukkan nilai koefisien korelasi (r) antara variabel prestasi belajar dengan perencanaan karir siswa adalah sebesar 0,597 dan $p$ value 0,0000. Nilai determinan (r2) sebesar 35,7 \%, sehingga hal ini menunjukkan bahwa prestasi belajar memberikan sumbangan positif dan signifikan terhadap perencanaan karir siswa, dapat disimpulkan bahwa: ada hubungan positif dan signifikan antara prestasi belajar dengan perencanaan karir pada siswa kelas XI SMA Negeri 2 Bantul. Hasil penelitian ini dapat dijadikan sebagai bahan pertimbangan bagi guru bimbingan dan konseling dalam meningkatkan prestasi belajar dan perencanaan karir siswa melalui layanan bimbingan dan konseling, dan bagi sekolah menjadi bahan pertimbangan dalam pengembangan kurikulum untuk meningkatkan pretasi belajar siswa.
\end{abstract}

Kata Kunci: prestasi belajar, perencanaan karir

The learning achievement is an aspect that must be considered by the student, because it can affect career planning. Seeing this, the students are expected to have a maximum learning achievement. Reality is still a lot of students who have grades below a minimum completeness criteria (KKM). This study aims to determine the relationship between learning achievement in the career planning class XI student of SMAN 2 Bantul Academic Year 2014/2015. This research is a correlation, the variables of this study is twofold learning achievement variable $(\mathrm{X})$ and career planning variable $(\mathrm{Y})$. The population in this study is a class XI student of SMAN 2 Bantul Academic Year 2014/2015. The sample in this study a class XI student with the number of 37 students, pengembilan sample by random (random sampling). The collection of data on achievement variable learn to use data documentation, that the data value of report cards, and on career planning variables using a questionnaire. This validity test analysis using product moment formula, the analysis of the reliability test using Cronbach alpha formula, while data analysis using product moment formula. The results of this analysis demonstrate the value of the analysis of the correlation coefficient (r) between the variables of learning achievement of students with career planning amounted to 0.597 and $\mathrm{p}$ value 0.0000 . Value of the determinant (r2) of $35.7 \%$, so this shows that learning achievement contributes a positive and significant impact on student career planning, it can thus be concluded that: there is a positive and significant relationship between achievement of learning with career planning in class XI SMAN 2 Bantul Academic Year 2014/2015.

Keywords: learning achievement, career planning

\section{Pendahuluan}

Pendidikan memiliki peranan yang sangat penting dalam upaya menciptakan generasi manusia yang berkualitas baik. Upaya peningkatan kualitas ini ditujukan untuk mewujudkan para pemuda-pemudi yang mampu bersaing dalam dunia modern dalam upaya mencerdaskan kehidupan bangsa. Dilihat pada kenyataan saat ini, kualitas pendidikan Indonesia sangat rendah, dapat dilihat pada kurikulum yang hanya didasarkan pada pengetahuan pemerintah tanpa memperhatikan kebutuhan dari kebanyakan siswa.

Setiap siswa atau individu dalam menuntut ilmu di sekolah mengharapkan dapat memperoleh suatu peningkatan pengetahuan dan keterampilan setiap jenjang pendidikan yang lebih tinggi. Peningkatan pengetahuan ini merupakan suatu 
upaya untuk pencapaian masa depan yang baik. Pencapaian masa depan yang baik dapat dilihat dari kesuksesan karir siswa pada masa depan. Kesuksesan karir merupakan suatu pengukuran pencapaian keberhasilan karir, yang dapat dilihat dari tingkat kepuasan karir yang dirasakan oleh individu. Hal ini tentu diinginkan oleh para remaja agar masa dewasa nanti dapat sukses dalam karir, namun kesuksesan karir akan dapat dicapai oleh siswa yang mampu memiliki perencanaan karir. Siswa yang memiliki perencanaan karir yang rendah akan kesulitan dalam upaya mewujudkan kesuksesan karir.

Kecakapan dalam mengambil keputusan, merupakan tujuan utama dari perencanaan karir yang harus ditempuh oleh setiap individu dan dengan perencanaan karir, remaja dapat mempersiapkan diri memasuki masa dewasa dengan baik. Proses perencanaan karir akan memperoleh pengetahuan tentang potensi yang ada pada individu yang meliputi bakat, keterampilan, minat, pengetahuan, motivasi dan karateristik individu yang digunakan sebagai dasar dalam pemilihan yang kemudian dilanjutkan dengan menentukan tahapan untuk bisa mencapai karir yang sudah dipilih. Pada proses tersebut tentu masih banyak remaja yang belum paham atau belum mengetahui apa potensi (bakat, minat, dan keterampilan) yang mereka miliki.

Masalah karir kongkrit yang dirasakan oleh siswa menurut Supriatna (dalam Juwitaningrum, 2013) antara lain: a) siswa kurang memahami cara memilih program studi yang cocok dengan kemampuan dan minat, b) siswa tidak memiliki informasi tentang dunia kerja yang cukup, c) siswa masih bingung memilih pekerja, d) siswa masih kurang mampu memilih pekerjaan yang sesuai dengan kemampuan dan minat, e) siswa merasa cemas untuk mendapatkan pekerjaan setelah tamat sekolah, f) siswa belum memiliki pilihan perguruan tinggi atau lanjutan pendidikan tertentu, jika setelah tamat tidak memasuki dunia kerja, dan g) siswa belum memiliki gambaran tentang karakteristik, persyaratan, kemampuan, dan keterampilan yang dibutuhkan dalam pekerjaan serta prospek pekerjaan untuk masa depan karirnya. Permasalahan-permasalahan tersebut menggambarkan bahwa siswa kurang matang dalam perencanaan karir. Terdapat beberapa faktor yang mempengaruhi perencanaan karir remaja. Salah satu faktor tersebut yaitu prestasi belajar (hasil belajar) remaja.

Prestasi belajar merupakan hasil usaha belajar yang berupa nilai-nilai sebagai ukuran keberhasilan siswa, yang ditunjukan dengan jumlah nilai rapor. Prestasi belajar yang baik merupakan suatu harapan dari setiap diri siswa, namun melihat kenyataan saat ini masih banyak siswa yang belum memiliki prestasi belajar yang baik. Pembahasan pada rapat majelis guru di Jawa Tengah, masih ada beberapa orang siswa yang belum tuntas secara keseluruhan matapelajaran yang diujikan. Walaupun persentasenya rendah tapi itu cukup untuk menggagalkan target 100 persen yang ingin dicapai (Kompasiana, 2012)

Mengkaji dari berita edukasi kompasiana, dapat dilihat bahwa masih banyak siswa yang memiliki prestasi belajar yang kurang baik, yaitu memiliki nilai dibawah kriteria ketuntasan minimal (KKM). Hal ini tentu akan sulit dalam upaya mewujudkan tujuan pendidikan untuk mencerdaskan kehidupan bangsa. Usaha memberikan siswa untuk dapat memperoleh suatu prestasi dan suatu peningkatan pengetahuan serta keterampilan akan juga sulit untuk terwujud.

Pada masa remaja prestasi belajar merupakan suatu titik kritis atau tanggung jawab remaja untuk penunjang karir di masa dewasa. Menurut Santrock (2007: 147) remaja merupakan suatu titik kritis dalam hal prestasi, tekanan social, dan akademis. Hal ini memaksa remaja untuk memegang berbagai peran yang sering kali melibatkan tanggung jawab yang lebih besar. Di masa remaja, prestasi menjadi persoalan yang lebih serius dan remaja mulai memandang keberhasilan dan kegagalan di masa depan ketika dewasa nanti.

Mengkaji dari pernyataan di atas, dapat dilihat bahwa remaja memiliki titik kritis berkaitan tentang prestasi belajar, hal tersebut merupakan tekanan sosial dan akademis sebagai tanggung jawab untuk mencapai kesuksesan karir ketika remaja sudah beranjak pada masa dewasa. Tanggung jawab ini merupakan kewajiban siswa untuk dapat meningkatkan prestasi belajar, agar mampu mencapai kesuksesan karir pada masa dewasa. Berdasarkan paparan di atas, dapat dilihat bahwa masih banyak siswa yang kebingungan dalam merencanakan karir, dan belum paham/ mengetahui potensi yang dimiliki 
remaja, serta rendahnya prestasi belajar pada siswa.

Berdasarkan wawancara kepada dua guru BK yang mengampu kelas XI di SMA Negeri 2 Bantul, yang dilakukan pada tanggal 14 Juli 2014, diperoleh informasi bahwa siswa kelas XI di SMA Negeri 2 Bantul yang memiliki prestasi belajar yang kurang baik maka memiliki perencanaan karir yang kurang baik pula, berbeda dengan siswa yang memiliki prestasi belajar yang baik maka cenderung memiliki perencanaan karir yang baik. Hal ini terjadi karena siswa yang memiliki prestasi belajar baik, mampu mengetahui potensi di suatu bidang studi tertentu, sehingga siswa mampu mengembangkan potensi tersebut untuk persiapan karir siswa di masa depan, sedangkan siswa yang memiliki prestasi belajar rendah akan kesulitan dalam merencanakan karir karena siswa belum mampu melihat potensi yang dimiliki, sehingga siswa juga belum mampu mengembangkan potensi yang dimiliki untuk perjalanan karir siswa ke depan.

Penelitian ini bertujuan untuk mengetahui hubungan prestasi belajar dengan perencanaan karir siswa SMA. Prestasi belajar yang baik, dapat memudahkan siswa untuk mengembangkan potensi dirinya dalam suatu bidang tertentu. Dengan demikian, siswa dengan mudah merencanakan karirnya di masa depan. Hasil penelitian ini dapat dijadikan sebagai bahan pertimbangan bagi guru bimbingan dan konseling dalam meningkatkan prestasi belajar dan perencanaan karir siswa melalui layanan bimbingan dan konseling, serta bagi sekolah menjadi bahan pertimbangan dalam pengembangan kurikulum untuk meningkatkan pretasi belajar siswa.

\section{Kajian Literatur}

\section{Remaja}

Remaja merupakan masa mencari identitas diri. Menurut Suherman (2007: 105) masa remaja adalah periode perubahan. Periode yang dimaksudkan adalah perubahan dalam sikap, perilaku, ataupun fisik. Adapun Konopka (Yusuf, 2011: 10) menjelaskan bahwa masa remaja adalah segmen kehidupan yang penting dalam siklus perkembangan siswa dan merupakan masa transisi (dari masa anak ke masa dewasa) yang diarahkan kepada perkembangan masa dewasa yang sehat.

Parson \& Grinder (dalam Suherman, 2007: 105) menjelaskan juga berdasarkan perspektif belajar sosial, bahwa masa remaja adalah masa senang bergaul dengan teman sebaya karena dipandang menewarkan social reward dan peer status needs yang lebih menarik dari pada keluarga. Berdasarkan beberapa pendapat di atas, maka dapat disimpulkan bahwa masa remaja adalah masa transisi dari masa anak ke masa dewasa, yang ditandai dengan senang bergaul dengan teman sebaya dan ditandai juga pada perubahan sikap, perilaku, serta perubahan fisik.

Desmita (2010: 190) penggolongan remaja terbagi menjadi tiga tahap yaitu: "12-15 tahun = masa remaja awal, 15-18 tahun = masa remaja pertengahan, 18-21 tahun = masa remaja akhir”. Masa remaja awal secara umum individu telah memasuki pendidikan dibangku sekolah menengah pertama, sedangkan remaja tengah, individu telah memasuki sekolah menengah atas/SMA, dan untuk remaja akhir secara umum mereka telah memasuki dunia kerja atau pendidikan perguruan tinggi.

\section{Perencanaan Karir}

Perencanaan karir menyangkut masa depan dalam jangka panjang yang harus direncanakan sejak jauh hari. Upaya mewujudkan keinginan karir yang dicapai, individu melakukan suatu proses identifikasi terhadap diri individu. Proses identifikasi tersebut yaitu berupa mengidentifikasi potensi, bakat, dan minat sehingga mampu menyesuaikan dengan karir yang dipilih. Simamora (2011: 504) menjelaskan bahwa perencanaan karir adalah proses untuk menyadari diri sendiri terhadap peluang-peluang, kesempatan-kesempatan, kendala-kendala, pilihan-pilihan, dan konsekuensi-konsekuensi, mengidentifikasi tujuan-tujuan yang berkaitan dengan karir. Berdasarkan pendapat di atas, maka dapat disimpulkan bahwa perencanaan karir merupakan suatu proses pemilihan sasaran karir, dengan menyadari terhadap peluang, kesempatan, kendala, dan pilihan-pilihan karir untuk mencapai dari tujuan karir yang dinginkan.

Perencanaan karir melibatkan pengidentifikasian tujuan-tujuan yang berkaitan dengan karir dan penyusunan rencana-rencana untuk mencapai tujuan tersebut. Menurut 


\section{APRIANSYAH}

Simamora (2011: 505) perencanaan karir merupakan proses yang bertujuan untuk: 1) menyadari diri sendiri terhadap peluang-peluang, kesempatan-kesempatan, kendala-kendala, pilihan-pilihan, dan konsekuensi-konsekuensi; 2) mengidentifikasi tujuan-tujuan yang berkaitan dengan karir; 3) menyusun program kerja, pendidikan dan yang berhubungan dengan pengalaman-pengalaman yang bersifat pengembangan guna menyediakan arah, waktu dan urutan langkah-langkah yang diambil untuk meraih tujuan karir. Berdasarkan pendapat di atas, maka dapat dijelaskan bahwa tujuan perencanaan karir adalah menyadari terhadap adanya peluang, kesempatan, serta kendala dan pilihan, dan juga mengidentifikasi tujuan-tujuan yang berkaitan dengan karir.

Winkel dan Hastuti (2012: 682-683) menyatakan bahwa tujuan dari perencanaan karir meliputi tujuan jangka waktu panjang (long range goals) dan tujuan dalam jangka waktu pendek (short-range goals). Tujuan jangka waktu panjang adalah tujuan dari perencanaan yang dicapai waktu yang akan datang dalam kurun waktu yang lama. Tujuan jangka waktu panjang misal gaya hidup (life style) yang ingin dicapai, dan nilai-nilai kehidupan yang ingin direalisasikan dalam hidup. Tujuan jangka waktu pendek adalah tujuan yang dibuat oleh individu untuk lebih memantapkan pilihan yang diambil, mengetahui informasi lebih luas mengenai bidang jurusan serta informasi perguruan tinggi, tempat kursus atau pekerjaan yang sesuai dengan jurusan yang telah diambil. Berdasarkan pendapat di atas, maka dapat disimpulkan bahwa tujuan perencanaan karir terdiri dari tujuan jangka waktu panjang dan tujuan jangka waktu pendek. Tujuan jangka waktu panjang adalah tujuan dari perencanaan yang dicapai waktu yang akan datang dalam kurun waktu yang lama. Tujuan jangka waktu pendek adalah tujuan yang dibuat oleh individu untuk lebih memantapkan pilihan yang diambil, mengetahui informasi lebih luas mengenai bidang jurusan serta informasi perguruan tinggi, tempat kursus atau pekerjaan yang sesuai dengan jurusan yang telah diambil.

Pada aspek perencanaan karir, terdapat indikator-indikator seperti yang dikemukakan oleh Suherman (2007: 116) antara lain: 1) mempelajari informasi karir; 2) membicarakan karir dengan orang dewasa; 3) mengikuti pendidikan tambahan (kursus); 4) berpartisipasi dengan kegiatan ekstrakurikuler; 5) mengetahui persyaratan pendidikan untuk karir yang diinginkan; 6) dapat merencanakan apa yang harus di lakukan setelah tamat dari sekolah; 7) mengetahui cara dan kesempatan memasuki karir yang dinginkan; 8) mengatur waktu luang secara efektif. Selain beberapa hal diatas, terdapat aspekaspek perencanaan karir yang juga harus diperhatikan. Menurut Jordan (Yusuf, 2009: 27) aspek-aspek dalam perencanaan karir meliputi: a) pemahaman karir; (b) mencari informasi; c) perencanaan dan pengambilan keputusan.

\section{Prestasi Belajar}

Siswa membutuhkan usaha yang sunguhsunguh untuk mendapatkan prestasi belajar yang baik. Menurut Syah (2010: 149) prestasi belajar merupakan hasil belajar atau hasil penilaian menyeluruh. Sudjana (2010: 22) mengungkapkan bahwa prestasi belajar adalah kemampuankemampuan yang dimiliki siswa setelah siswa menerima pengalaman belajar. Berdasarkan paparan tersebut, maka dapat disimpulkan bahwa prestasi belajar adalah kemampuan yang didapatkan oleh seorang siswa dari proses belajar dan proses belajar tersebut dinilai dari hasil belajar siswa.

Menurut Sugihartono (2007: 131) ada dua macam pendekatan untuk mengevaluasi atau menilai tingkat keberhasilan/prestasi belajar: 1) norm-referencing atau norm-referenced assessment (Penilaian Acuan Norma); dan 2) criterion-referencing atau criterion reference evaluation (Penilaian Acuan Patokan).”

Penilaian acuan norma adalah penilaian yang dilakukan dengan membandingkan hasil belajar seorang siswa terhadap hasil belajar siswa lain dalam kelompok. Patokan ini dapat dikatakan sebagai patokan yang nyata, yang artinya patokan pembanding nilai semata-mata diambil dari kenyataan yang diperoleh dari pengukuran keseluruhan nilai yang didapat dari sekelompok siswa. Penilaian acuan patokan adalah penilaian yang dilakukan dengan membandingkan hasil belajar siswa terhadap suatu patokan yang telah ditetapkan. Patokan ini bertujuan untuk menetapkan pengukuran suatu hasil belajar, sehingga dapat menetapkan pengukuran batas lulus. 
PRESTASI BELAJAR, PERENCANAAN KARIR

Berdasarkan paparan tersebut, maka dapat disimpulkan bahwa pendekatan untuk mengevaluasi atau menilai tingkat keberhasilan/ prestasi belajar dapat dilakukan dengan dua macam yaitu melalui penilaian acuan norma (norm-referenced assessment) dan penilaian acuan kriteria (criterion-referenced assessment). Upaya dalam pemaksimalan prestasi belajar, memiliki faktor-faktor yang mempengaruhi, yaitu faktor eksternal maupun faktor-faktor internal.

. Menurut Slameto (2010:54) menyatakan Faktor internal yang mempengaruhi prestasi belajar sebagai berikut: 1) faktor jasmani, 2) faktor psikologis, 3) faktor kelelahan. Sedangkan faktor eksternal yang mempengaruhi prestasi belajar antara lain sebagai berikut: 1) Faktor keluarga, 2) faktor sekolah, 3) faktor masyarakat. Faktor yang mempengaruhi prestasi belajar antara lain faktor eksternal dan faktor internal. Faktor eksternal yaitu faktor yang berasal dari luar diri individu, sedangkan faktor internal adalah faktor yang berasal dari dalam diri individu

\section{Metode Penelitian}

Penelitian ini menggunakan jenis penelitian korelasional dengan pendekatan kuantitatif. Penelitian ini dilakukan di SMA Negeri 2 Bantul. Populasi dalam penelitian ini adalah siswa kelas XI SMA Negeri 2 Bantul. Sampel dalam penelitian berjumlah 37 siswa kelas XI yang diambil dengan random sampling. Pengumpulan data pada variabel prestasi belajar menggunakan data dokumentasi yaitu data nilai rapor dan pada variabel perencanaan karir menggunakan instrumen angket perencanaan karir siswa dengan indikator: 1) pemahaman karir, 2) mencari informasi, 3) perencanaan dan pengambilan keputusan. Analsis data dilakukan dengan uji korelasi menggunakan rumus product moment.

\section{Hasil Penelitian dan Pembahasan}

Data yang telah dikumpulkan melalui kuisioner tentang perencanaan karir dan prestasi belajar siswa melalui nilai rapor kemudian digunakan untuk keperluan scoring. Berdasarkan paparan data pada Tabel 1, dapat diketahui bahwa nilai rata-rata prestasi belajar 37 siswa adalah 83,27.
Tabel 1

Deskripsi Data Variabel Prestasi Belajar

\begin{tabular}{ccccc}
\hline $\begin{array}{c}\text { Skor } \\
\text { Max }\end{array}$ & $\begin{array}{c}\text { Skor } \\
\text { Min }\end{array}$ & Range & Mean & SD \\
\hline 89,00 & 79,30 & 9,70 & 83,27 & 2,94 \\
\hline
\end{tabular}

Prestasi belajar siswa digolongkan dalam tiga kategori yaitu rendah, sedang, dan tinggi. Tabel 2 menunjukkan bahwa dari 37 siswa kelas XI SMA Negeri 2 Bantul, prestasi belajar pada kategori tinggi sebanyak 7 siswa (18,9\%), dan prestasi belajar dalam kategori sedang yaitu sebanyak 22 siswa (59,5\%), dan 8 siswa (21,6\%) mempunyai prestasi belajar rendah.

Kecenderungan variabel prestasi belajar dapat dilihat dengan mean objektif dan kriterian ideal. Nilai raport prestasi belajar menghasilkan skor terendah ideal sebesar 79.3 dan skor tertinggi ideal sebesar 89,0. Berdasarkan perhitungan diperoleh kategori ideal sebagai berikut: 86,21-89,00 dalam kategori tinggi, 80,34-86,21 dalam kategori sedang, dan 79,30-80,34 dalam kategori rendah. Mean (M) objektif pada prestasi belajar sebesar 83,27 dan dibandingkan dengan kriteria ideal, maka dapat disimpulkan kecenderungan prestasi belajar berada pada kategori sedang. Berdasarkan perhitungan, kategorisasi variabel prestasi belajar siswa dapat dilihat pada Tabel 2.

Tabel 2

Distribusi Frekuensi Prestasi Belajar Siswa

\begin{tabular}{lllll}
\hline Kategori & Interval & Frekuensi & Prosentase \\
\hline Tinggi & 86,21 & s.d. & 7 & $18,9 \%$ \\
& 89,00 & & & \\
Sedang & 80,34 & s.d & 22 & $59,5 \%$ \\
& 86,21 & & & \\
\multirow{5}{*}{ Rendah } & 79,30 & s.d & 8 & $21,6 \%$ \\
& 80,34 & & & \\
\multicolumn{2}{c}{ Total } & & 37 & $100 \%$ \\
\hline
\end{tabular}

Perencanaan karir siswa kelas XI SMA Negeri 2 Bantul sebagian besar berada pada kategori sedang. Kecenderungan variabel prestasi belajar dapat dilihat dengan mencari mean objektif dan kriterian ideal. Nilai raport prestasi belajar menghasilkan skor terendah ideal sebesar 121 dan skor tertinggi ideal sebesar 184. Berdasarkan perhitungan diperoleh kategori ideal sebagai 


\section{APRIANSYAH}

berikut: 161,99-184 dalam kategori tinggi, 131,58-161,99 dalam kategori sedang, dan 121-131,58 dalam kategori rendah, karena mean (M) objektif pada prestasi belajar sebesar 146,78 dan dibandingkan dengan kriteria ideal, maka dapat disimpulkan kecenderungan perencanaan karir berada pada kategori sedang. Hasil perhitungan variabel perencanaan karir dapat dilihat pada Tabel 3 dan distribusi frekuensi perencanaan karir siswa dapat dilihat pada Tabel 4.

Tabel 3

Deskripsi Data Variabel Perencanaan Karir

\begin{tabular}{lllll}
\hline $\begin{array}{l}\text { Skor } \\
\text { Max }\end{array}$ & $\begin{array}{l}\text { Skor } \\
\text { Min }\end{array}$ & Range & Mean & SD \\
\hline 184 & 121 & 63 & 146,78 & 15,20 \\
\hline
\end{tabular}

Tabel 4

Distribusi Frekuensi Perencanaan Karir Siswa

\begin{tabular}{cccc}
\hline Kategori & Interval & Frekuensi & Prosentase \\
\hline Tinggi & $\begin{array}{c}161,99 \\
\text { s.d. } 184\end{array}$ & 5 & $13,5 \%$ \\
Sedang & $\begin{array}{c}131,58 \\
\text { s.d. }\end{array}$ & 26 & $70,3 \%$ \\
& 161,99 & & \\
Rendah & 121 s.d. & 6 & $16,2 \%$ \\
& 131,58 & & \\
\multicolumn{2}{c}{ Total } & 37 & $100 \%$ \\
\hline
\end{tabular}

Uji persyaratan analisis yang digunakan dalam penelitian ini adalah uji normalitas sebaran dan uji linieritas huibungan. Uji normalitas digunakan untuk melihat normal atau tidaknya distribusi jawaban subjek pada suatu variabel yang dianalisis. Sebaran subjek mengikuti kurva normal menunjukan bahwa alat ukur layak dijadikan sebagai alat pengumpul data karena representative dengan populasi yang ada, namun apabila tidak mengikuti distribusi frekuensi normal maka alat ukur tidak layak dijadikan alat pengumpul data.

Uji normalitas dalam penelitian ini menggunakan statistik Kolmogorov-Smirnov. Distribusi data dikatakan normal ketika mempunyai $p$ value $>0,05$, sedangkan dikatakan mempunyai sebaran tidak normal ketiika mempunyai $p$ value $\leq 0,05$. Pada Tabel 5 diketahui nilai $p$ value untuk masing-masing variabel prestasi belajar dan perencanaan karir adalah 0,332 dan 0,710>a=0,05. Hasil ini menunjukkan bahwa skor variabel prestasi belajar dan perencanaan karir mempunyai sebaran normal. Hasil uji normalitas dengan statistik Kolmogorov-Smirnov (K-S) dapat dilihat pada Tabel 5.

Tabel 5

Uji Normalitas Sebaran

\begin{tabular}{lccc}
\hline \multicolumn{1}{c}{ Variabel } & $\begin{array}{c}\text { K-S } \\
\text { Hitung }\end{array}$ & P Value & Hasil \\
& 0,946 & 0,332 & Normal \\
\hline $\begin{array}{l}\text { Prestasi } \\
\text { Belajar } \\
\begin{array}{l}\text { Perencanaan } \\
\text { Karir }\end{array}\end{array}$ & 0,700 & 0,710 & Normal \\
\hline
\end{tabular}

Uji linieritas digunakan untuk mengetahui ada tidaknya korelasi antara dua variabel. Uji linieritas dalam penelitian ini bertujuan untuk mengetahui ada tidaknya korelasi antara prestasi belajar dengan perencanaan karir pada siswa kelas XI SMA Negeri 2 Bantul Yogyakarta. Kaidah dalam uji linieritas adalah jika nilai $p$ value pada deviation from linierity $>0,05$ maka dikatakan ada hubungan linier. Jika nilai $p$ value pada deviation from linierity $\leq 0,05$ maka dikatakan tidak ada hubungan linier. Pada Tabel 6 , nilai $\mathrm{F}$ hitung $=0,553$ dengan $p$ value $0,875>\alpha$ $=0,05$. Hasil ini menunjukkan bahwa ada hubungan linier antara prestasi belajar dengan perencanaan karir pada siswa kelas XI SMA Negeri 2 Bantul Yogyakarta. Hasil uji linieritas dapat dilihat pada Tabel 6 .

Tabel 6

Uji Linieritas Hubungan

\begin{tabular}{cccc}
\hline Variabel & F Hitung & P Value & Hasil \\
\hline Prestasi & 0,553 & 0,875 & Linier \\
Belajar- & & & \\
Perencanaan & & & \\
Karir & & & \\
\hline
\end{tabular}

Kebenaran hipotesis dalam penelitian ini dapat dibuktikan menggunakan korelasi product moment Pearson's. Langkah-langkah pengujian hipotesis yang pertama yakni merumuskan hipotesis. Adapun rumusan hipotesis: 1) Ho: Tidak ada hubungan positif antara prestasi belajar 
dengan perencanaan karir pada siswa kelas XI SMA Negeri 2 Bantul Yogyakarta; 2) Ha: Ada hubungan positif antara prestasi belajar dengan perencanaan karir pada siswa kelas XI SMA Negeri 2 Bantul Yogyakarta.

Langkah yang kedua yakni menentukan nilai $\mathrm{R}$ tabel dan daerah kritis. Nilai $\mathrm{r}$ tabel pada derajat bebas $(\mathrm{db})=\mathrm{n}-2=35$ dengan $\alpha=0,05$ adalah 0,325 . Daerah kritis pada panelitian ini: 1 ) Ho ditolak jika nilai $r$ hitung $>0,325$ atau $p$ value $<\alpha=0,05$; dan 2) Ho diterima jika nilai $r$ hitung $\leq 0,325$ atau $p$ value $\geq \alpha=0,05$.

Langkah yang ketiga yaitu membandingkan Nilai R Hitung dengan R Tabel. Hasil perhitungan dengan program SPSS menunjukkan nilai $\mathrm{r}$ hitung $=0,597$ dengan $p$ value 0,000 . Nilai $\mathrm{r}$ hitung $=0,597>0,325$ ( $\mathrm{r}$ tabel) dengan $p$ value $0,000<\alpha=0,05$ maka Ho ditolak. Hasil ini menunjukkan bahwa ada hubungan positif yang signifikan antara prestasi belajar dengan perencanaan karir pada siswa kelas XI SMA Negeri 2 Bantul.

Nilai korelasi product moment Pearson's antara prestasi belajar siswa dengan perencanaan karir sebesar 0,597. Hal ini menunjukkan bahwa hubungan antara kedua variabel tersebut bersifat positif yang berarti bahwa semakin tinggi prestasi belajar siswa maka ada kecenderungan semakin tinggi pula perencanaan karir siswa. Nilai koefisien determinasi yang merupakan kuadrat dari korelasi sebesar 0,357. Hasil ini mempunyai arti bahwa besarnya variasi dari perencanaan karir yang dapat diterangkan oleh prestasi belajar siswa adalah 35,7 \% dan sisanya sebesar 64,3\% dari perencanaan karir disebabkan oleh variabel lain diluar prestasi belajar siswa.

Hasil penelitian ini menunjukkan bahwa ada hubungan positif antara prestasi belajar dengan perencanaan karir pada siswa kelas XI SMA Negeri 2 Bantul Yogyakarta. Hal ini mempunyai arti, jika siswa memiliki prestasi belajar yang baik, maka cenderung siswa akan baik pula di dalam merencanakan karir. Begitu pula sebaliknya, jika siswa cenderung memiliki prestasi belajar yang kurang baik, maka siswa kurang baik pula di dalam merencanakan karir. Prestasi belajar siswa yang meningkat akan diikuti dengan kemampuan siswa dalam melakukan perencanaan karir yang baik.

Prestasi belajar adalah kemampuan yang didapatkan oleh seorang siswa dari proses belajar, dan proses belajar tersebut dinilai dari hasil belajar siswa. Prestasi belajar siswa yang rendah akan menjadi hambatan dan berpengaruh bagi siswa dalam merencanakan karir karena prestasi belajar dapat menjadi faktor penghambat siswa dalam merencanakan karir. Melihat hal tersebut, maka siswa harus mampu meningkatkan prestasi belajar. Apabila siswa sudah mampu meningkatkan prestasi belajar, maka siswa dapat merencanakan karir dengan baik dan terarah sesuai dengan prestasi yang telah didapatkan oleh siswa.

\section{Simpulan}

Berdasarkan hasil yang diperoleh dari analisis data penelitian dan pembahasan, maka dapat disimpulkan bahwa: Ada hubungan positif dan signifikan antara prestasi belajar dengan perencanaan karir pada siswa kelas XI SMA Negeri 2 Bantul. Artinya jika siswa memiliki prestasi belajar yang baik, maka cenderung siswa akan baik pula di dalam merencanakan karir. Begitu pula sebaliknya, jika siswa cenderung memiliki prestasi belajar yang kurang baik maka siswa kurang baik pula di dalam merencanakan karir. Hasil penelitian ini dapat dijadikan sebagai bahan pertimbangan bagi guru bimbingan dan konseling dalam meningkatkan prestasi belajar dan perencanaan karir siswa melalui layanan bimbingan dan konseling, serta bagi sekolah menjadi bahan pertimbangan dalam pengembangan kurikulum untuk meningkatkan pretasi belajar siswa.

\section{Referensi}

Desmita. (2010). Psikologi Perkembangan. Bandung: PT Remaja Rosdakarya

Hikmawati, Fenti. (2010). Bimbingan Konseling. Jakarta: PT Raja Grafindo Persada.

Juwitaningrum, Ita. 2013. Program Bimbingan Karir untuk Meningkatkan Kematangan Karir Siswa SMK. PSIKOPEDAGOGIA Jurnal Bimbingan dan Konseling, 2(2): 64-78.

Natawijaya, Rochmat. (2003). Konseling Kelompok: Konsep Dasar dan Pendekatan. Bandung: Rizqi Press

Nurihsan, Achmad Juntika. (2006). Bimbingan dan Konseling. Bandung: PT Refika Aditama 


\section{APRIANSYAH}

Santrock, John W. (2007). Remaja. Jakarta: Erlangga

Simamora, Henry. (2011). Manajemen Sumber Daya Manusia. Yogyakarta: YKPN

Slameto. (2010). Belajar dan Faktor-Faktor Yang Mempengaruhi. Jakarta: Rineka Cipta

Sudjana, nana. (2010). Penilaian Hasil Proses Belajar Mengajar. Bandung: Remaja Rosdakarya

Sugihartono. et al. (2007). Psikologi Pendidikan. Yogyakarta: UNY Press

Suhesti, Endang Ertiati. (2012). Bagaimana Konselor Sekolah Bersikap?. Yogyakarta: Pustaka Pelajar

Suherman, Uman. (2007). Konseling Karir Sepanjang Rentang Kehidupan. Bandung: Universitas Pendidikan Indonesia
Syah, Muhibin. (2010). Psikologi Belajar. Jakarta: Raja Grafindo Persada

Winkel, \& Sri Hastuti. (2012). Bimbingan \& Konseling di Institusi Pendidikan. Yogyakarta: Media Abadi

Yusuf, Syamsu. (2009). Program Bimbingan \& Konseling di sekolah. Bandung: Rizqi Press

Yusuf, Syamsu. (2011). Psikologi Perkembangan Anak \& Remaja. Bandung: PT Remaja Rosdakarya

. (2012). Nilai US di Bawah KKM Siapa Salah. (Online). (http://edukasi.kompasiana.com/2012/12/20/nilaius-di-bawah-kkm-siapa-salah. html), diakses 15 maret 2014, 07.49 WIB). 